\title{
The Interpretation of Islamic Education: Perceptions of Modernist and Classical Thinkers on The Qur'anic Exegesis
}

Received: 10-01-2021 Revised: 05-02-2022 Accepted: 09-02-2022

\section{Yusuf Olawale Uthman, Owa-Onire ${ }^{1}$}

Faculty of Islamic Studies, Department of Tafsir, Ibn Haldun University, Turkey ${ }^{1}$

Email: mushfiqy@gmail.com

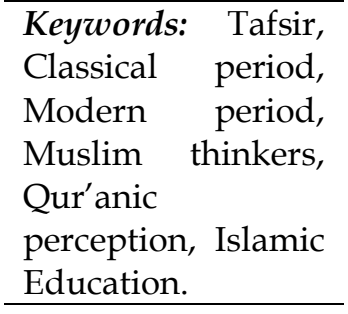

\section{INTRODUCTION}

As for the sake of truthfulness and integrity, it is indeed the right period, that there is a need for scholarly attention on the effort to restore the high rate of appropriate interpretation of the Islamic revelation. The eminent author, Bilal Aybkan, ${ }^{1}$ happened to be a well-versed scholar on Islamic jurisprudence and a respected personality in another area of Islamic disciplines in our time. In their article " Some Observations on Islamic Legal Studies in Turkey" they mentioned that penetration into the actual text required

1 Prof. Dr. Bilal Aynakan is the Dean of The Department of Islamic Studies, Ibn Haldun University, Istanbul Turkey. 
skillful academia in various disciplines of Islamic knowledge such as law, economics, politics, sociology, history, theology, linguistics, semiotics, semantics, hermeneutics, philosophy, religion, exegesis, tradition, logic, and classical figh science, in addition to knowing the strategic way of Orientalist to disputing their falsehood. While it is quite unfortunate that some eminent researchers conveyed their findings to argue that the link between the sacred book Qur'an and social life is incompatible with each other in this modern time. Therefore, according to them, we have to deviate from the traditional structure of ruling to engage in a new methodology. ${ }^{2}$ Is there any reasonable sense of reasoning with this perspective?

The scholar Bilal Aybakan, in this same article, also discussed the affection of western thought in some of these personalities like Fazlurrahman, Jabiri, Hasan Hanafi, Nasr Hamid Abu Zayd, and Muhmmad Arkoun were mentioned to have suspicious views on Islamic heritage; because they are known to be influenced with the connection to the ideology of the orientalist and the critiques of Islam to evacuate the wellrecognized dignity of the traditional Muslim community. ${ }^{3}$ In this regard, the current study consulted the relevant books, journals, and journal articles that will help to distinguish between the sincere scholar and prominent authorities that engaged the contextual traditional course of Islam, from the other parts that may have views subjected to expert's corrections.

Accordingly, the book of Yahiya Emerick "The Complete Idiot's Guide to Understanding Islam" does represent the message of this research, in the sense of presenting the Islamic teachings and faith in the right way of deriving appropriate meanings of Islamic texts, to avoid misunderstanding. The author argues that the Islamic religion can be referred to as the way of life, a religion of peace that emerges as the living spirituality with the faith or the belief. The religion that was established over 1,400 years and still meets up with the challenges facing the human race and provides their needed and possible solutions. ${ }^{4}$

Similarly, the work of Abdul-Raof Hussein "School of Qur'anic Exegesis: Genesis and Development rules out the lines to the fundamental knowledge of the Qur'an's

2 Aybakan, Bilal. Some Observations on Islamic Legal Studies in Turkey. M.Ü. Ilâhiyat Fakültesi Dergisi, 2007, 31.2006/2: 133-62.

${ }^{3}$ Ibid.

4 Emerick, Yahiya. The Complete Idiot's Guide to Understanding Islam: A Thoughtful Exploration of Islamic Culture and Beliefs. (Alpha: a Pearson Education Company, 2004) pp. 18-19. 
interpretation, with an adequate academical approach. ${ }^{5}$ Hence, the ethical and credible Muslim scholars and thinkers in the classical era earned their reputation in Islamic disciplines, likewise the competent ones among the right thinkers in the modern period.

Consequently, this study will analyze the perspective of both classical thinkers and the modernist ones to elucidate comparably the appropriate ways of interpreting the religious texts 'nusus' in both periods. However, our readers -by God's grace- will be able to identify the rich and appropriate perspective in getting to the end road of our article.

\section{Short View of The Qur'an}

The revelation of the sacred book the "Qur'an" meant to be the scripture sent down by Allah (SWT) to His messenger; Prophet Muhammad (saw) received the revelational message during the first century of Islam at the moment of twenty-three years at Makkah (610-622) and Madinah (622-632). The verses that were revealed first are verses 1-5 of Chapter 96 was the last chapter revealed to the prophet according to Bukhari (d. 256/870) and Muslim's (d. 262/875) reports from the wife of the Prophet Aysha (d. 59/678) (r.a) in al-itqon of Suyuti (d. 2081/1505) and also the last verse revealed to the prophet was the verse 281 of chapter 2 of the Quran in the same book.

In addition, following the generated cognizance about the revelation in the matters of Tafsir and its thoughts, before diving into the topic; the definition of the word Tafsir in lexical and technical meaning should be provided. Shortly the word Tafsir (Exegesis) is a standard Arabic word; Fassara (he explain), Yufassiru (he is explaining), Tafsiran (explanation), here the meaning is to clarify or to explain some things the Exegete is called Mufassir in the Arabic language. Zarkashi (d. 794/1392) in al-Itqon stated that Tafsir is known as a scientific study of the book of Almighty Allah (Qur'an) that was revealed to prophet Muhammad (peace be upon him), by explaining its meaning and deriving all its aggregate classical rules. ${ }^{6}$

\footnotetext{
5 This great book was highly recommended by Prof. Dr. Bilal Aybakan- we plead Allah to preserve him upon goodness- while he is taking us an important lecture named "formation of Islamic studies", 2019. That is the first year of our Master's course work in the Department of Islamic Studies, at Ibn Haldun University Istanbul, Turkey.

${ }^{6}$ al-jalal as-Suyuti, Abdul Rahman bin Abubakir bin Muhammad. Al-itqon fii ulum Al-Qur'an, (Cairo: Dārul Fajir Lil turāth, 201) v.1, p. 71-72

al-jalal as-Suyuti. al-itqon, 2010, v. 2. pp. 461.
} 


\section{The Perceptions of Qur'anic Exegesis (tafsir) in the Classical Period}

\section{The Tafsir in The First Century of Islam}

Generally, Tafsir is referred to as available discipline since the lifetime of the prophet; in the first century, the exegesis of the Quran is a Constance assignment upon the prophet-hood via the commandment from Allah to his messenger (peace be upon him), this can be traced when his lord steered him to explain His word to his companions in precise and the state as a whole, Allah states: And We have also revealed the Dhikr to you, so that you may explain to men what was once revealed to them, so that possibly they may observe themselves" (Q16:44). Ibn Kathir (d. 773/1372) (may Allah have mercy on him) said: That is due to the fact you comprehend the meaning of what is revealed to you, and you are very eager about it and comply with it, and due to the fact, We recognize that you are pleasant of creation and the leader of the sons of Adam, you will explicate to them in specific what is stated in brief, and you will explain to them what they cannot understand. "And that they might also give thought" means: so that they might also conceptualize themselves and be guided, and therefore gain salvation in both the kingdom [The world and the Hereafter]. ${ }^{7}$ It's nicely understood in this noble verse that the Dhikr is the Quran, which the prophet is in the cost of instructing its teachings to the Muslims in this period.

Utterly the prophetic lifestyle is desirable for referring to the discipline of Quranic exegesis, due to the fact of his role as a messenger of Allah (SWT), who have the bountiful chance of receiving the blessed book (Quran) Allah says in His word Q59:7 " Anything the Messenger has introduced to you take it, and what he has forbidden you to abstain from it". The Islamic pupils agree that the prophet himself vindicated this factor to Muslim Ummahs that there are sure works of supplication which had been no longer declared in the Qur'an, meanwhile, the lifestyle of Muhammad (peace be upon him) will be in the role to explain or make clear what used to be no longer stated virtually in the Quran and that was once the meaning deriving from the forthcoming Hadith: "Take your rituals from me" he additionally said, "pray as you have considered me pray". 8

\footnotetext{
7Ibn Katheer, Ismail b. 'Umar b. Katheer. Tasir al-Qur'an al-Azim. (Riyād: Dāru t-Tayba li Nashr wa Tawzi', 1999) v. 4, pp. 573.

8al-Qurtabi, Abu Abdullah Muhammad b. Ahmad b. Abi Bakr al-Ansāri al-Khaziraji. al-Jamiu li Ahkāmi al-Qur'an, (Cairo: Dāru al-Kutub al-Misriyah, 1997) v. 1, p. 37
} 
However, the exegesis of the prophetic exegesis is primarily based on the following technical expression: explaining the worshiping matters: like his clarification towards the ayah: "And confirm the prayer and pay the Zakat" (Q2:42). This is defined via the prophet's word: Learn your rites from me and pray as you noticed me praying. Then his exegesis clarifies the complicated words: This sort of interpretation is made when the prophet defined the means of the verse of (Q2:186) Allah states: "Eat and drink till the white thread of sunrise is cleared to you from the black thread of night". Udai b. Hatim narrated that he requested the prophet about this verse and whether or not it means the black and white thread? But he answered (No, it is the darkness of the nighttime and the lightness of the day). Likewise, specifying the genetic troubles and restrictions on the unrestricted are amongst the elements of his tafsir (saw) ${ }^{9}$

In addition, in the first century, we also have the exegetes amongst the companions, who manifest to be the excellent college students of the prophet. In the first line of counting their names, the four guided caliph; Thus, many narrations of exegesis are no longer attributed to some of them due to the preoccupied with the caliphate activities, and there have been many students of Quranic interpretation amongst them, so there used to be no need to transmit their self. Duly their perceptions of interpretation are primarily based on what they understood from their dear teacher, the prophet (saw). Thus, there have been well-known companions with the many transmissions of exegesis of the Qur'an their names and brief fictions are as follows: Ali b. Abi Talib: 'Abdullah b Mas'ud (d. 33/653), Ibn Ghafil al-Hudhali, 'Ubay b. Ka'b (d. 29/649), Zayd b. Thābit (d. 40/660), 'Abdullah b. 'Abbas (d. 68/687), Abu Musa al- Ash'ari (d. 42/662), and Abdullah b. Zubayr (d. 73/692). these are the most well-known companions in the subject of Quranic exegesis in the first century of Islam (blessings of Allah be upon every one of them). $\cdot^{10}$

Similarly, some scholars like as-Suyuti introduced three companions to this list, like Anas b. Malik (d. 94/712), Abu Hurayra, 'Abdullah b. 'Umar (d. 74/693), Jabir b.

\footnotetext{
${ }^{9}$ Ibn Kathir, Tasir al-Qur'an al-Azim, 1999, v. 3, p. 290.

10 al-Tabari, Muhammad ibn Jarir. Jāmi 'al-bayān 'an ta'wìl āy al-Qur'ān. (Cairo: Dāru Tawfiqiyah li Tibā'a, 2013) v. 1, pp. 15-19.
} 
'Abdullah (d.78/697), Abu Musa al- Ash'ari. Compared to the firstmentioned listing their transmission of exegesis is not many. ${ }^{11}$

\section{The Exegetical Perceptions of Tafsir in The Second Century of Islam}

Historically the Qur'anic exegesis was once exposed to the stage of recording its materials, after the tournament of gaining knowledge of it with the aid of learning by heart that befell in the first century. In the famous Islamic book, which is at-Tafsir, wa alMufassirun al-Dhahabi expounds that the second century of Islam convey forth the writings of Tafsir and it used to be recognized to commence at the end of the Umayyads regime (d.41/661-132/749), which is the beginning of the tenure of 'Abbasids empire $(132 / 749)$ and exist until today. Before this time the understanding is that exegesis used to be via transmission from prophet utilizing companions and between themselves, the successors additionally exceeded through this avenue of transmission. ${ }^{12}$

Besides, in the second century, the exegesis has been gathered alongside the hadith; some Ayahs have been mixed with the hadith and transmitted by way of the scholars of hadith like Yazid b. Harun al-Salami (d.117/735), Shu'bah b. al-Hajjaj (d.160/776), Sufyan al-Thawri (d.161/777), Waki' b. al-Jarrah (d.197/812), Sufyan b. 'Uyainah (d.198/813), Ruh b. 'Ubadah al-Basri (d.205/820), 'Abd al-Razzaq al-San'ani (d.211/826), Adam b. Abi Iyas (d.220/835) and 'Abd b. Humaid (d.249/863). ${ }^{13}$ Imam asSuyuti (d.911/1506) in al-Itqon stated this opinion. ${ }^{14}$

The Quranic exegesis received its independence, in a very short time from the margins with the Hadith. This indication can be addressed as the complete recording segment of the exegesis of the Quran when many Islamic disciplines, like Islamic jurisprudence and theology, have been technically derived and received their maturities from Quranic exegesis understanding. ${ }^{15}$ There are many exegetes for the work of recording some surahs and Ayah; they are well-known for this venture to date, they are as follows: al-Dahhak b. Muzahim al-Balkhi (d.105/723), Muqatil b. Sulaiman al-Balkhi (d.150/767), 'Abd al-Malik b. 'Abd al- 'Aziz b. Juraij (d.80150/699-767), Sufiyan b. Sa 'id b. Masruq al-Thawri (d.161/777), Yahya b. Salam (d.124-

\footnotetext{
11al-jalal as-Suyuti. al-itqon, 2010, v. 2. pp. 496-497.

12 al-Dahabi, Muhammad al-Seyyid Hussain. at-Tafsir wa al-Mufassirun. (Cairo: Maktabatu Whabah, 2000) v. pp. 104.

13Yasir Qadhi, Abu Ammaar. An Introduction to the Sciences of the Qur'an. (1999) pp.298.

14 al-jalal as-Suyuti, Al-itqon fii ulum Al-Qur'an. (2010) v. 2, pp. 498.

15 Abdul Rauof, School of Quranic exegesis genesis,(2010) P. 161.
} 
200/741-815), Abu Zakariya 'Abdullah al-Farra' (d.207/822), Abu Bakr 'Abd al-Razzaq al-San'ani (d.211/826), Ibn Majah (d.273/886), Ibn Jarir al-Tabari (d.310/922), Abu Bakr b. al-Mundhir al-Naisaburi (d.318/930), 'Abd al-Rahman b. Abi Hatim (d.327/938), Abu al-Shaikh b. Habban (d.369/979), al-Hakim (d.405/1014) and Abu Bakr b. Mirdawaih (d.410/1019). Generally, these stated exegetes of the classical duration centered in their thought, on the prophetic narration as properly as the partner transmission in their Quranic interpretation. Moreover, the narration from the companion's scholar is additionally a reference to them, in short, the concept of their exegesis can be known as the revelational exegesis (al-Tafsir bil-Mathur).

According to some opinions, the first exegete who accumulated and interpreted the Quran from the starting to the end was: Muqâtil b. Sulaiman (d. 150/767). Some pupils stated Ali b. Abi Talha (d. 143/760) due to the fact of his book: Saifeh Ali b. Abi Talha in Quranic interpretation, whilst some of them stated is, Abu Zakariya Yahya b. Ziyad al-Ferrâ (d. 207/822) and his e book is "Mâni'al-Quran". Also, Ibn "Ashûr (d.1393/1973) stated Abdul Malik b. Juraij (d. 150/767) was once the first that recorded Tafsir. ${ }^{16}$ However, many outstanding records evaluate that Muqâtil b. Sulaiman is the first individual who interpreted the Quran from beginning to end as was once noted above. ${ }^{17}$

Whereas all these stated exegesis books have been primarily based on explaining the ambiguous, deciphering the Quran linguistically, or deriving the event of the Quran and they introduced in their works unique methods of studying the Quran.18

\section{The Exegetical Perceptions of Tafsir in The Third Century of Islam}

The Tafsir has won advancement in its notion due to many semantic explanations applied to it in this classical period. However, the quotations from preIslamic Arabic poetry and Arabic linguistics are brought to their works in this century. The spreading of Islam has located this type of improvement in the discipline of Tafsir. To restore greater perception about the Quranic meanings. The exegetes of the third century of Islam developed their capabilities of exegesis with these quotations in more than a few disciplines of Islamic knowledge. Among the exegetes that focal point on this

16Ibn 'Ashûr, Muhammad Tahir b. Muhammad b. Muhammad. at-Tahrir wa at-Tanwir, Tunis: (Daru atTunisiyah li Nashr, 1984) v. 1, 14.

17 Cerrahoglu, Ismail. Tafsir Tarihi. Mizanul-Hak İslamer Dergi (Ankara: frcr Yayınları, 2015), 8:249-256.

18 Doğan, Mehmet Zeki-Güneş Abdülbaki. A Brief Overview to The Historyof Tafsiri. (İlahiyat, 2019). no. 2, p. 10: $47-66$ 
noted grammatical evaluation methodology is Abu 'Ubaidah Ma'amar b. al-Muthana (d. 210/826), in his book Majaz al-Quran, al-Farra' (d. 207/823) in his work referred to as Maa'ni al-Quran, and al-Akhfash in his book Maa'ni al-Quran, ${ }^{19}$ Muhammad b. Mustanir al-Basri is recognized as Qatrab (d. 211/827) he is Mu'tazili and he additionally has his work referred to as Ma'ani al-Quran, Abu 'Ubaid al-Qasim b. Salam al-Hiwari (d. 224/839)) in his work Ma'ani al-Quran, in accordance to ad-Dahabi is the first scholar to write a written book about the linguistic meaning of the Quran and his work is noted to be the Ma'ani al-Quran, we also have Qatrab, al-Akhfash, and others. Then this current list we nevertheless have the work of Abu Muhammad Abd-Allah b. Muslim b. Qutayba alDinawari (d. 276/890); Gharib al-Quran and Ta'wil Mushkil al-Quran, al-Hussain b. alFadil b. 'Umair al-Bajali (d. 282/896) his work in Arabic contest is additionally Ma' ani alQuran, ad-Dahabi, and different scholars testify to his Tafsir scholarship, Ismail b. Ishaq b. Hammad b. Zayd al-Azdi al-jahadami (d. 282/896) work is accessible with the title Ma'ani al-Quran, Abu Ishaq az-Zujaj (d. 311/924) in Ma'ani al-Quran wa I'irabuhu; his work is the biggest amongst the preceding grammatical exegesis of Arabic literature, Abu Ja'far Ahmad b. Muhammad b. Ismail an-Nahas (d. 338) his work is named I'irab al-Quran wa Ma'ani al-Quran, and the closing exegete in this listing is Muhammad b. alKaraji al-Qasab (d. 360/971) his work Nakatu al-Quran ad-Dalah 'a'la al-Bayan. ${ }^{20}$

Similarly, the Islamic theological reflection in Tafsir, pupils of this superb discipline also contributed an educative perception to Quranic exegesis in this unique period. Islamic groups aside from Ahl Sunnah are recognized as Ahl awah (people of selfdesire) and are known as Ahl Bid 'ah (people of innovation) in tafsir literature. The political ideology encouraged them to reject the Ahl Sunnah's exegesis. Meanwhile, they misplaced it all with a lot of errors in the direction of the interpretation of the Quran. Therefore, their non-mainstream of Tafsir is rejected by scholars of Tafsir and Islamic theologians. Among these groups that had been counted at some point of the classical segment of Tafsir are Shi'ah, al-Qadariyyah, and al-Murji'ah. Thus, the exegetes amongst the companions are free of these sects, they solely made their existence reins in the mix of successor's exegetes. ${ }^{21}$ According to Ayoub Shi'te's beliefs

${ }^{19}$ Ibn Jma'ah, Muhammad. at-Tatawwur at-Tarikhi li Harakat t-Tafsir. Multaka Ahl Tafsir. Multaka Ahl Tafsir. 2010.

20 al-Mutayri, 'Abdul Aziz b. Dakhil, Tarikh Tadwin al-Tafsir, Jamharat al-Ulum, Muntada Jamharat alUlum,( January 09, 2021)

${ }^{21}$ Abdul Rauof, School of Quranic exegesis genesis, (2010) P. 184 
that the prophet is the only legit interpreter of the Quran then their grasp in their doctrine, any different scholars are no longer acceptable. ${ }^{22}$

On the other hand, the super books of Tafsir that belong to authors from perceptions of Ahl Sunnah are the benefits as far as all Islamic disciplines inclusive of Tafsir is concerned. Distinctively, the most well-known pupils of theology amongst Ahl Sunnah in this generation are Abu Mansur al-Maturidi (d. 333/945) with the book Tawilat Ahl Sunnah, and Abu al-Layth al-Samarqandi (d. 373/984) his work is referred to as Bahrul 'Ulum. ${ }^{23}$ They both emphasize many theological issues in their works. Repeatedly spoke back to any opinion that may want to be instigating the concept of Ahl Sunnah. For instance, the textual evaluation of alMaturidi will serve as clarification of this concept. During the interpretation of a verse in the Q2:255 in his work, he states: " And the Almighty said: (Who is he who intercedes with him barring with his permission), the meaning: No one dares to intercede barring his permission. So, there are variations of opinions on intercession:

The Mu'tazila said: Intercession is solely for people of correct deeds, specifically those who have not sinned, or they have sinned, so they repented totally. They primarily based their proof on the phrase of Allah: (The angels: who maintain the throne and surrounded it, they are praising their Lord by way of thanksgiving and additionally trust in Him, and ask forgiveness for these believers. O Lord and are seeking for all mercy and word forgive these who repent and observe your path and store them from the torment of hell), Mu'tazila, in this verse it was once advised that they would ask for forgiveness for these who trust and repent and follow. If the forgiveness in this world is only for those who believe, repent, and follow, then that intercession is only for these believers in the hereafter. Direct reply from $\mathrm{Abu}$ Mansur: As for us (Ahl Sunnah): the intercession maintained that is also for human beings of sins. Simply because anyone does no longer sin does not need intercession. This is the theological problem between Abu Mansur and Mu'tazila which described the theological perception of Quranic exegesis in this third century. ${ }^{24}$

As for the tafsir's concept in this era, Hadith and jurisprudence additionally have a mirrored influence on the perceptions of an exegete in that period. Hence, many wellknown jurists represented the noble effort in the Quranic exegesis avenue with their jurisprudential credibility such as Muhammad b. Idris ash-Shafi'i (d. 204/820), It was 1189

${ }^{22}$ Ayoub, M. Muhmoud. The Quran and Its Interpreters.(New York: Sunny Press, Albany, 1948) v. 1, PP.

23as-Shamilah. Kutub at-Tafasir. al-Maktabat as-Shamilah, January 09, 2021.

24 al-Maturidi, Muhammad b. Muhammad b. Muhammad Abu Mansur. Tawilat Ahl Sunnah, (Beirut: Darul-Kutub al-'Ilmiyah, 2005) v.2 p. 236-237. 
once stated that even though he did not dedicate a book on the interpretation of the Quran. However, it has a wonderful impact on scholars in dealing with the troubles of Tafsir. He revived the understanding of the pilgrims, constant the guidelines of inference, confirmed what may want to be referred to as the equipment wished for the interpreter, and deposited in his books especially what is in his ar-Risalah of that if it has been accrued and singled out and defined with the aid of its examples, it would have been of the most useful that for a scholar of exegesis studies. ${ }^{25}$

Therefore, the mainstream kind of exegesis is mirrored in the notion of exegetes and Muslim thinkers, and the prophetic traditions and that of companions and their successors in Tafsir have been employed to strategy the spiritual matters. For an instant, we have the work of that outstanding exegete Ibn Jarir al-Tabari (d. 310) in the remaining section of the third century.

Particularly Tabari's work, Jami' al-Bayan a ta'wil ay al-Quran has the concept of focusing on the mainstream factor of Quranic exegesis in this period. In phrases of Tafsir bil riwayah, interpretation of the Quran is based totally on the prophetic legacy and narrations from companions as properly as the successors. In the book, Tabari emphasized the exploitation of the Arabic language. He realized that grasping the grammatical context is very necessary to an exegete. Tabari's obstinate faith matters, by using citing the views of scholars in Islamic sects such as Sunni, Ash'arites, Mu'tazilah, and Jabarites sect. ${ }^{26}$ Although concerning the theological problem he looks to select Sunni's opinion. For occasion all through his dialogue on the word of Allah: "Then He became to the heaven; He then proportioned them as seven heavens, and He is allKnowing of everything" Q2:29. As it was once referred to above; in his interpretation of this verse, he mentions the opinions and then chooses the idea of Ahl sunnah. That the phrase Istawa' in Arabic has many meanings. And here in the verse, it described the highness of Allah and His Superior power on His creature; which is the heavens. ${ }^{27}$

The above-mentioned perspectives belong to the classical exegetes and Muslim thinkers, and it is recognized to be the usual interpretations of the Qur'anic text. While

\footnotetext{
25 al-Mutayri, 'Abdul Aziz b. Dakhil, Tarikh Tadwin al-Tafsir, Jamharat al-Ulum. Tarikh Tadwin al-Tafsir, Website link available, (2021).

26 Asyraf Hj Ab Rahman, Firdaus Khairi Abdul Kadir, and others. The Development of Tafsir from the Prophet Muhammad Down to Ibn Kathir. The Social Sciences, medwell journals, 12 n. 2 (2017). 1818-5800.

27 al-Tabari, Muhammad ibn Jarir. Jāmi 'al-bayān 'an ta'wìl ày al-Qur'ān. (Cairo: Dāru Tawfiqiyah li Tibā'a, 2013) v.1 p. $454-457$
} 
genuine exegesis is endorsed with the then exegetes. On the different hand, the modernist approach has reformed the remarkable ideas of the classical era. In the feel that, every thinker can be allowed to suppose over the signification of the sacred book, in which there is that trust that Qur'an interpretation is no longer restrained only to the religious exegetes or jurists of Islam. ${ }^{28}$

\section{Qur'anic Exegesis in The Perceptions of Modernist Muslim Thinkers}

Contrary to the perception of Muslim exegetes and thinkers towards the Qur'an and its interpretation in the classical period, this is majorly based on the mainstream and traditional exegesis. The thought of Quranic exegesis in modern stylistics can be described as what is gained and influenced by synchronous socio-political needs and scientific modification which have led to the growth of an education in exegesis that recognized accounting for the modern knowledge base, medical matters, social condition, and governmental improvement. ${ }^{29}$ Therefore, there are claims, in this section which the modernists are on the fact that there is nothing in the Quran that is contrary to the laws of human nature.

\section{The Typical Components of The Modernist's Exegesis}

Talking of the component that enhances modern exegesis, the idea of radio exegesis (al-tafsir al-idha'i) is known as synoptic in the modern phase in the second half of the twentieth century. The main objective of this tafsir is to simplify the meanings of the Qur'an for the radio's audience. However, features of this tafsir are time limitation, considering the type of audience, topic of the program, thematic unit, simplicity and brevity, outline, neglecting the Jewish anecdotes, and radio vocal skills. This perception of tafsir is traced to the work of the following Islamic thinkers; Fu'ad al-'Irris's tafsir book is originally a Lebanese radio program broadcast through the Qur'an radio (idha'at alQur'an). However, it is intended to serve as an educative program to the audience. Some other radio exegesis broadcasts are by Muhammad al-Makki al-Nasiri (d.1994) (Morocco), 'Abdullah al-Tayyib (d.2003) (Sudan), Fadil Hasan 'Abbas (Jordan), Muhammad al-Sa'adi FTayyib(Egypt), Wahbah Mustafa al-Zuhaili (Syria; al-Damir 2006), Muhammad al-Nabulsi (Palestine) and 'Isa 'Abdu (Saudi Arabia). ${ }^{30}$

\footnotetext{
28 Serjeant, R. B. JMS Baljon: Modern Muslim Koran interpretation. (Guilders 19. Bulletin of the School of Oriental and African Studies, 1963) pp. 16.

${ }^{29} \mathrm{Abdul}$ Rauof, School of Quranic exegesis genesis, (2010) pp. 145.

${ }^{30} \mathrm{Ibid}, \mathrm{pp} .120$.
} 


\section{More Illuminations and Examples}

Among the major component that enhances the modern perceptions of Muslim thinkers, for instance, are critics. The western critics raised allegations on certain permissible topics of Islam, like jihad, polygamy, and slavery. The modern thinker, Seyyid Ahmad Khan, is among those that, employed an effort to the evolution of reinterpretation of the Qur'an in the modern phase. He analyzes these topics in his defensive perception, in which he made the questioner understand that the concept of jihad or prophet's maghazi (militant expedition), is the historical circumstance of pagan Arabia, and also is in the international code of war always. So Seyyid Ahmad Khan mentioned that the raids again the enemies are not limited to Islam only, but it has been the notable institution that was established for defensive warfare. Just as the same case that is discovered in the warfare of Hebrew prophets with the absence of a single apology. ${ }^{31}$

Meanwhile, as for the question of slavery, he used modern thought to argue that in the Islamic view human being has been created freely, and slavery and freedom cannot in any way co-exist or get together. He expressed that most societies based on religion or philosophy, like christen, Jewish, and Greco-Roman, only sanctioned slavery. However, Islam is the only religion that condemned and rejected slavery. Therefore, the Qur'an only refers to slaves then existing in the early stage of Islam. The slavery mentioned in Quran is social order inherited from pagan Arabia, and it could only be slowly abolished within "a generation" but not last long. The verse 47:5 of the Quran: "Then set them free, either by grace or ransom" is clear evidence of the prohibition of fresh enslavement. In this regard, there is no inference on slavery institution or new enslavement problems in the text of the Qur'an that is main to seize freedom of human beings. ${ }^{32}$ The modernist interpretation treats the question of polygamy by stating that it's only prohibited if demonstrated with built-in shortcomings. Aside from that, the Quran permitted it; this is cleared in the verse of the Qur'an 4:3:

"If you fear you cannot act fairly towards the orphans then marry the women you like two, or three, or four. But if you fear you will not be fair, then one, or what you already have. That makes it more likely that you avoid bias."...

${ }^{31}$ Aziz Ahmad, Islamic modernism in India and Pakistan Aziz Ahmad. (London: Oxford University Press, 1964) pp. $50-51$

32Ibid. 
It is noted in the verse that polygamy is prohibited in Islam when a man is incapable of loving more than one wife.

Further, the perception of modernist Muslim thinkers is also reflected in the economic system, just as there is a question on the interest on the loan (riba). This matter of loan on interest has been the relationship to the development of the modern Islamic state and its banking system in the future. Thus, this perspective is different from what was understood in the early centuries of Islam when it was categorically forbidden in Islam. On the other hand, the modern thinker, Seyyid Ahmad Khan, in his modern interpretation has maintained that compound interest might not be considered as forbidden, but simple interest. Apart from that bank interest or any interest on government bonds should be considered permissible. ${ }^{33}$

Consequentially another illustration of the modernist tafsir is whether nasiq and manssuq (abrogation) are no more in the Quran like it's said in the classical period, however, is no agreement on the number of verses with the application of this rule. Meanwhile, modernists like Ahmad Khan and 'Abd al-Hakim are not too please with attributing the rule to the Quran. For example, Seyyid Qutub stated that the verse: S2:173/178, which is considered to be abrogated with another verse S. 5:49/45, he explained that two separate topics have been discussed in the two verses. The first topic is dealt with personal relations issues, while the second verse is addressing joint or collective retribution. Although Tantawi Djawhari reclaimed that the abrogation might exist as the greatest secret of progress and the finest rays that shining over humanity, since God has shown human beings how night and day abrogate each other, for this reason, the abrogation also can be considered in this perspective. ${ }^{34}$

\section{CONCLUSION}

Consequently, one has to read the Quran and understand it by asking many questions that will solve newly arising problems by consulting the sacred book with appropriate meanings. As it was mentioned in this study, the Quranic tafsir has passed by hermeneutic style from the early century of Islam. Thus, mainstream exegesis and traditional tafsir trends in the classical period. While the exegetes and Muslim thinkers

\footnotetext{
33 Ibid., pp. 52-53.

34 Serjeant, R. B. JMS Baljon: Modern Muslim Koran interpretation, 1963. pp.49.
} 
based their interpretation upon the transmission with limited issues, due to the early stage of Islam. Contrarily, the perceptions of modernists are much related to the newly generated matters in societies. The modern Muslim thinkers employed efforts on the defensive position, in front of the enemy of Islam, whenever there is an attempt of ridiculing the principles of this great religion with sort of lies. They are, however, disputes these barbaric acts, with the genuinely versed and modern interpretation of the Holy Quran.

\section{REFERENCES}

Al-Qur'an al-Kareem

Abbott Nabia, Tefsir'in Erken Dönem Gelişimi, tr. Mehmet Akif KOÇ, AÜİFD v. XUII no. 2 (2002): 449-462.

Abdul-Raouf, Hussein. School of Qur'anic Exegesis: Genesis and Development. London and New York: Routledge, 2010.

Asyraf Hj Ab Rahman, Firdaus Khairi Abdul Kadir, and others. The development of Tafsir from the Prophet Muhammad Down to Ibn Kathir. The Social Sciences, Center for fundamental and liberal Education, Universiti Malaysia Terengganu, medwell journals, 12 (2) (2017)

Aziz Ahmad, Islamic modernism in India and Pakistan Aziz Ahmad. London: Oxford University Press, 1964.

Aybakan, Bilal. Some Observations on Islamic Legal Studies in Turkey. M.Ü. Ilâhiyat Fakültesi Dergisi, 2007, 31.2006/2: 133-62. (Accessed September 20, 2021). http://openaccess.marmara.edu.tr/bitstream/handle/11424/1540/200614.pdf?sequence $=1$.

Cerrahoglu, Ismail. Tafsir Tarihi. Mizanul-Hak İslamer Dergi Ankara: frcr Yayınları, 2015.

al-Dahabi, Muhammad al-Seyyid Hussain. at-Tafsir wa al-Mufassirun. Cairo: Maktabatu Whabah, 2000.

Emerick, Yahiya. The Complete Idiot's Guide to Understanding Islam: A Thoughtful Exploration of Islamic Culture and Beliefs. Alpha: a Pearson Education Company, 2004.

Ibn 'Ashûr, Muhammad Tahir b. Muhammad b. Muhammad. d.1393H. at-Tahrir wa atTanwir, Tunis: Daru at-Tunisiyah li Nashr, 1984 
Ibn Jma'ah, Muhammad. at-Tatawwur at-Tarikhi li Harakat t-Tafsir. Multaka Ahl Tafsir. Multaka Ahl Tafsir. (Accessed July 16, 2010). https://vb.tafsir.net/forum/

Ibn Kathir, Ismail b. 'Umar b. Katheer. d.774H. Tasir al-Qur'an al-Azim. ed. Sami b. Muhammad Salāmat, Dāru t-Tayba li Nashr wa Tawzi': Riyād, 1999.

al-jalal as-suyuti, Abdul Rahman bin Abubakir bin Muhammad. d.911H, "Al-itqon fii ulum Al-Qur'an", ed. Hamid Ahmad At-tair Al-basyuni, 2nd ed. Cairo: Dārul Fajir Lil turāth, 2010.

al-Maturidi, Muhammad b. Muhammad b. Muhammad Abu Mansur. d.333H. Tawilat Ahl Sunnah, ed. Majidi Baslum, 1' ${ }^{\text {st }}$ ed. Beirut: Darul-Kutub al-'Ilmiyah, 2005.

al-Mutayri, 'Abdul Aziz b. Dakhil, Tarikh Tadwin al-Tafsir, Jamharat al-Ulum, Muntada Jamharat al-Ulum (Accessed January, 09, 2021). https:/ /jamharah.net/showthread.php?t=28080.

al-Qurtabi, Abu Abdullah Muhammad b. Ahmad b. Abi Bakr al-Ansāri al-Khaziraji. d.671H. al-Jamiu li Ahkāmi al-Qur'an. ed. Ahmad al-Barduni, Ibrahim Atfish, 2nd ed. Cairo: Dāru al-Kutub al-Misriyah, 1997.

al-Tabari, Muhammad ibn Jarir. d.310H. Jāmi 'al-bayān 'an ta'wūi ày al-Qur'ān. ed. Hāni al-Hāj, 'Amād Zeky al- Bārudy, Khayry Sa ' heed, 3rd ed. Cairo: Dāru Tawfiqiyah li Tibā'a, 2013.

as-Shamilah. Kutub at-Tafasir. al-Maktabat as-Shamilah, Accessed January 09, 2021. https://al-maktaba.org/category/127.

Serjeant, R. B. JMS Baljon: Modern Muslim Koran interpretation. (Guilders 19. Bulletin of the School of Oriental and African Studies, 1963.

Yasir Qadhi, Abu Ammaar. An Introduction to the Sciences of the Qur'an. United Kingdom: Al-Hidaayah Publishing and Distribution, 1999. 